\title{
Organizing product innovation: hierarchy, market or triple-helix networks?
}

\author{
Rune Dahl Fitjar ${ }^{1 *+}$, Martin Gjelsvik ${ }^{2+}$ and Andrés Rodríguez-Pose ${ }^{3+}$
}

\author{
* Correspondence: \\ rune.d.fitjar@uis.no \\ ${ }^{\dagger}$ Equal contributors \\ ${ }^{1}$ UiS Business School, University of \\ Stavanger, Stavanger 4036, Norway \\ Full list of author information is \\ available at the end of the article
}

\begin{abstract}
This paper assesses the extent to which the organization of the innovation effort in firms, as well as the geographical scale at which this effort is pursued, affects the capacity to benefit from product innovations. Three alternative modes of organization are studied: hierarchy, market and triple-helix-type networks. Furthermore, we consider triple-helix networks at three geographical scales: local, national and international. These relationships are tested on a random sample of 763 firms located in five urban regions of Norway which reported having introduced new products or services during the preceding 3 years. The analysis shows that firms exploiting internal hierarchy or triple-helix networks with a wide range of partners managed to derive a significantly higher share of their income from new products, compared to those that mainly relied on outsourcing within the market. In addition, the analysis shows that the geographical scale of cooperation in networks, as well as the type of partner used, matters for the capacity of firms to benefit from product innovation. In particular, firms that collaborate in international triple-helix-type networks involving suppliers, customers and R\&D institutions extract a higher share of their income from product innovations, regardless of whether they organize the processes internally or through the network.
\end{abstract}

Keywords: Organization; Markets; Networks; Triple helix; Outsourcing; Firms; Norway

\section{Multilingual abstract}

Please see Additional file 1 for translations of the abstract into the five official working languages of the United Nations and Portuguese.

\section{Background}

Firm organization matters for innovation and for the returns that firms can extract from generating and/or adopting innovation. Firms that innovate more are expected to outcompete the market and earn a greater share of their revenues from the introduction of new products and services. However, the exact mechanisms which make a firm more or less innovative are still controversial. Firm-level innovation depends to a great extent on how firms organize the innovative effort. In recent years, many researchers have tended to highlight the importance of external links as a source of knowledge and innovation. Firms which develop external links connecting them with other firms, knowledge-creating centres, such as research centres and universities, and government bodies often find themselves at the centre of complex triple-helix networks which facilitate their capacity to innovate (Etzkowitz 2008; Leydesdorff 2000).

(c) 2014 Fitjar et al.; licensee Springer. This is an Open Access article distributed under the terms of the Creative Commons Attribution License (http://creativecommons.org/licenses/by/2.0), which permits unrestricted use, distribution, and reproduction in any medium, provided the original work is properly cited. 
On the other hand, the building and participation in triple-helix-type networks is often time-consuming and costly, while the knowledge generated within the networks is not always easy to process (Laursen and Salter 2006). By going beyond simple supply-chain collaborations, firms have to engage with agents that function in different ways and use different codes. As a result, and in contrast to the relatively straightforward relationship with suppliers and customers in order to generate product innovation, collaborations outside the supply chain may become more complicated, troublesome or unstable and disputes may arise over the ownership of outcomes. Firms may have to invest in absorptive capacity in order to access and transform external knowledge for their own use. It may be necessary to recruit highly skilled employees in order to communicate with universities, and government policies are not easily disentangled. Moreover, network theory posits that even if firms choose to procure new products externally, their relationship to suppliers is not necessarily best organized through arm's-length market transactions (Powell 1990; Uzzi 1996). If production processes have uncertain outcomes or require long-term commitment, the relationship between actors needs to be based more on trust than on pure cost-benefit analyses and is embedded in deeper social relations. This has advantages, but may also lead to more uncertain outcomes in terms of innovation. As a consequence, rather than getting involved in complex networks, firms may choose to simply rely on direct connections within the market (dyadic collaborations or partnerships), outsourcing innovation to suppliers or customers. Neo-classical economics holds that firms, being rational actors, will use information and production inputs that are available in the market if these are better or cheaper than what is available within the firm or in a network. This general assumption is expected to apply also to innovation activities, implying that firms that procure new product innovation from external suppliers may be able to introduce more new products and hence derive a larger share of their income from new innovations than those who fail to utilize this opportunity.

Outsourcing in the market is, nevertheless, again not without costs. Firms may thus find it best, in order to reduce the transactions costs and risks of outsourcing innovation to market agents or relying on triple-helix-networks, to organize innovation activities internally. This may be particularly true of actions with uncertain outcomes (Dodgson 2014), asymmetric information or which require specific investments, such as new product development. Under these circumstances, firms may choose to organize their innovation activities in-house in order to economize on transactions costs, limit risks and appropriate rents.

The geography of how the innovation effort is organized may also have an important influence on innovation and economic outcomes. This is, however, a factor which has been fundamentally overlooked by the literature. Triple-helix analyses about the formation of networks happen in what can be considered an ethereal space: complex networks can be developed in any sort of space, regardless of context and initial conditions (Etzkowitz 2003). When space is considered, the assumption is that most interaction will happen in constrained geographical spaces. Etzkowitz (2008, p. 8) indicates that 'triple helix initiatives take place at the regional level, where specific contexts of individual clusters, academic development, and presence or lack of governing authority influence the development of the triple helix'. Theories on agglomeration forces (Glaeser 2011), buzz (Storper and Venables 2004) and clusters (Porter 1998) assume 
that the benefits of knowledge diffusion are greatest when interaction takes place in close geographical proximity. A similar view has generally been taken in the triple-helix approach (Leydesdorff et al. 2006; Leydesdorff et al. 2006), meaning that interaction at a distance may be detrimental for the capacity of a firm to innovate. This assumption has been nonetheless challenged by recent research (Fitjar and Rodríguez-Pose 2013; Uzzi 1996) which has underlined the risks of lock-in in closely knit networks in constrained geographical spaces and, within the triple helix literature, by Leydesdorff, who indicates that 'with globalization, one can expect the international-national dimension to be increasingly relevant' (2012, p. 32).

The different forms of organization of innovation, and their geographies, may affect not only a firm's capacity to innovate but also how this innovation is translated into revenues and benefits. In this paper, we analyse the extent to which the prevalence of different organizations of innovation in the firm (market, hierarchy and triple-helix-networks (Powell 1990; Williamson 1991)) and the scope of the triple-helix networks, in terms of geography (links at local, national and international level) or types of partner (other firms, consultancies and $R \& D$ institutions), affect the share of income a firm derives from new products developed during the past 3 years. While innovation may take many different forms, the analysis focuses on innovation in the form of new product development and how this process is organized. This relationship is explored for a random sample of 763 Norwegian urban firms which reported product innovations as part of a larger survey of innovation in Norwegian city regions, which covered 1,600 firms in total. We find that both hierarchical and triplehelix network organization of product development are associated with a significantly higher share of income from new products than a pure market organization. Furthermore, hierarchical organization is also associated with a significantly higher share of income from new products than network organization. For collaboration in triple-helix networks, we find that geography is important, but in ways which have tended to be eschewed by previous analyses. Our results show that the diversity and geographical location of partners matter. Notably, firms that collaborate with a diverse set of international partners, including universities and research institutions, tend to derive a significantly higher share of their income from product innovations. The share of income from innovation is also higher when the product is new to the market, indicating that first movers are able to capture an entrepreneurial rent (Schumpeter 1934) that is not available to imitators.

\section{Markets, networks and firms}

Firms rely on three different forms of organizing innovation: markets, hierarchy, and networks (Powell 1990; Williamson 1991). At the firm level, these are three alternative modes of organization, the efficiency of which is determined by the characteristics of the transactions involved and the nature of the knowledge being transferred. At the macro or societal level, they represent three institutions in which the economy is organized. Hierarchy implies that innovation processes are organized internally within the boundaries of the firm. A market approach means that firms outsource their innovations to other market actors. The network mode denotes reciprocal and stable collaboration with other socioeconomic agents. The seed of networking in a system is interaction. We understand interaction as the reaction to the behaviour of another member within a system (Stogdill 1959). Interaction can be, on the one hand, sporadic and with no economic purpose or, by contrast, can be repeated in 
time and with some economic goal. When this happens among economic agents in a system, repeated interaction can lead to collaboration or partnerships, which can be defined as a shared commitment of resources to the mutually agreed aims of partners. These aims include developing new markets, gaining access to production and distribution networks, and addressing issues related to research, technology and innovation (Dodgson 2014). Collaborations or partnerships tend to be dyadic, that is, they generally involve two firms or two agents within a system. As a consequence, these dyadic outsourcing partnerships can be considered as different from broadly defined networks, which entail a multiplicity of - at least, more than two - economic agents establishing regular multilateral ties for purposes of information and knowledge sharing, services exchange and, ultimately, economic gain. When the networks involve economic agents from sectors which include firms, knowledgegenerating centres and government, the network becomes a triple-helix network, with purpose-built chains which churn out new knowledge and innovation (Etzkowitz and Leydesdorff 2000; Leydesdorff 2000). As Etzkowitz (2008, p. 50) posits, 'Whereas the traditional firm, with strong boundaries, is a nexus of contracts [...] the triple helix firm is part of a collaborative process that may include other firms and non-firm entities, such as university groups and government agencies'. These complex triple-helix networks involve a series of different purposes which range from simple collaboration, including collaborative leadership and conflict resolution, to substitution and technology transfer (Ranga and Etzkowitz 2013).

Which of these three modes of organization of the innovation effort is more efficient in terms of the bottom line and, more specifically, of the share of the profits that accrue to the firm from product innovations is still a matter of speculation. The characteristics of differentiated forms of innovation organization and of governing activities and transactions have been the focus of scholarly interest by institutional economists (Coase 1937; Williamson 1985, 1991), organizational sociologists (Granovetter 1992; Powell 1990), lawyers (Macneil 1980) and strategic management theorists (Barney and Ouchi 1986; Teece 2000), among others. Coase (1937) conceived the firm as a governance structure, a provocative break with the then orthodox view of the firm as an uninteresting 'black box' production function. He observed that entrepreneurs and managers weighed up the benefits of internal organization and production against the costs and risks of using markets. Williamson (1973) picked up this idea a generation later, in the 1970s, emphasizing that organizational form matters. In so doing, he moved the discipline of organizational economics closer to the field of organization theory and the strategic management literature. Williamson (1985) argues that transactions with highly uncertain outcomes, that recur frequently, and which require unique or transactionspecific investments are more likely to be organized within the boundaries of the firm. Transaction-specific investments cannot be easily transferred to other purposes and include resources in the form of money, time and energy. Other drivers have also been observed: the desire to increase incentive alignment through integrated ownership (Grossman and Hart 1986), the need for superior monitoring or measurement that can be done in-house (Barzel 1981), the inability to educate outside suppliers (Langlois 1992), the potential to capitalize on the firm's comparative or competitive advantages (Argyres 1996; Gulati et al. 2005) and fostering knowledge sharing and coordination (Conner and Prahalad 1996; Kogut and Zander 1996).

On the other hand, exchanges that are easy to define, standardized and with no specific investments needed to the particular transactions will take place in the market. 
Market-based exchanges are characterized as discrete contracts, often short-term, between autonomous buyers and sellers. These transactions are 'sharp in', indicating that they are accompanied by a clear-cut, complete and monetized agreement. They are also 'sharp out' in the sense that the provider's obligation of performance and the buyer's expected payment are unambiguous.

This academic discourse has developed in parallel with managerial practice. In recent decades, a trend for outsourcing has emerged. It is based on the assumption that a competitive advantage could be gained and sustained if external suppliers were contracted to carry out so-called non-core processes more efficiently. Several drivers for outsourcing have been reported: (i) economic - outsourcing allows economies of scale and the longevity of demand for the activity; (ii) quality - access to skills, the competency and specialization of potential suppliers and geographical coverage is increased; and (iii) innovation - improvements in quality through innovation, and the development of new services (Kakabadse and Kakabadse 2000). Outsourcing provides companies with greater capacity for flexibility, especially in access to rapidly emerging new technologies or the myriad of components in product development. In addition, outsourcing may have a potential to reduce the product design cycle time if multiple best-in-class suppliers who work simultaneously on individual components of the process are used (Quinn and Hilmer 1994).

Knowledge-based approaches have also been advanced to configure the optimal governance structure of activities. These contributions often emerge from the resourcebased literature on the strategy of firms (Barney 1991; Conner 1991; Peteraf and Helfat 2003), which might be seen as an alternative or a complement to transaction cost theory. Transaction cost theory conceptualizes the firm as a contractual entity with a strong focus on property rights, incentives and contracts. These issues are crucial when it comes to the appropriation of the benefits and rents of an innovation. When innovation processes are organized mainly within the boundaries of a firm, the property rights are unambiguous and the incentives more aligned. On the other hand, the knowledge- or resource-based perspective conceptualizes the firm as a repository of distinct productive knowledge, including the ability to learn and grow on the basis of that knowledge (Dosi and Kogut 1992; Foss 1996; Nickerson and Zenger 2004) and their related dynamic capabilities (Teece 2007; Teece et al. 1997). As the raw material for innovations is new combinations of knowledge and learning, this perspective is also important in studies of innovation processes. On this basis, we hypothesize that

Hypothesis 1: Firms that develop new innovations within the company will be more innovative than those who source innovations in the market.

A third way of organizing innovation is through networks, an approach which has become more prevalent in recent years. Historically, the market and the vertically integrated firm (hierarchy) were seen as a dichotomy. Exchanges could be arrayed along a continuum with discrete market transactions at one end and the integrated firm at the other. This continuum appears to have less and less explanatory power as firms are increasingly blurring their established boundaries to engage in neither the familiar alternative of arms'-length market contracting nor in the former ideal of vertical integration (Powell 1990). Powell (1990, p. 299) argues that 'by sticking to the twin pillars of markets and hierarchies, our attention is deflected from a diversity of organizational designs that are neither fish nor fowl, nor some mongrel hybrid, but a distinctly different form'. Some exchanges are dependent 
on relationships, mutual interests and reputation, and less guided by a formal structure of authority, but rather by networks and relational contracts (Macneil 1980).

Networks adopt many forms and shapes, but the exchange of information and knowledge tends to be maximized in dense triple-helix relationships involving firms with other knowledge-generating agents, such as governments, universities and research centres (Baum and Oliver 1991; Leydesdorff 2000). In these rich ecologies (Leydesdorff and Mayer 2006), repeated interaction within the network helps to disseminate knowledge, making firms involved in the network more dynamic and innovative than those outside it.

Triple-helix networks have been increasingly regarded as a superior form of innovation organization than markets or hierarchy. Polanyi (1944) classically noted that relations between economic actors are socially constructed and embedded in broader social structures. Building on this, Granovetter (1985) emphasized personal relations and networks of such relations as essential mechanisms for producing sufficient trust for market transactions to take place. He criticizes Williamson and other institutional economists for treating hierarchy as the solution to opportunism, noting that hierarchical structures do not produce trust between actors, and for ignoring the social relations in which firms and other economic actors are embedded. Organizing transactions in such networks of social relations 'are superior to pure authority relations in discouraging malfeasanse' (Granovetter 1985). Embedded, or networked, triple-helix relations thus provide a range of benefits to firms. They allow transfer of tacit and proprietary knowledge, enable joint and continuous problem-solving, and provide allocative efficiency (Uzzi 1996). As knowledge is increasingly distributed across a wide range of individuals and organizations, it has become important for firms to be able to mobilize both internal and external knowledge resources in pursuit of innovation (Chesbrough 2003; Foss et al. 2011; Tapscott and Williams 2006; Von Hippel 1988). Studies indicate that entrepreneurial opportunities emerge in the interplay between firm-specific capabilities and external knowledge (Audretsch and Keilbach 2007; Roper et al. 2008).

On this background, we expect that

Hypothesis 2a: Firms involved in triple-helix networks for the development of innovations will be more innovative than those which source innovations in the market or rely on internal and vertically integrated hierarchies.

However, in order for the network approach to promote innovation, partners - in a pure triple-helix logic - should be sufficiently differentiated to provide missing technologies or new or complementary capabilities (Osborn and Hagedoorn 1997). Being part of a diversified network (or several) will increase the number of ideas to select from. These advantages are further advanced if a firm is positioned in between differentiated networks, in the so-called structural holes (Burt 1992, 2004). For this reason, we extend on the question of whether or not a network mode is used by also considering the scope of the network. Firms collaborating with many different types of partners including other firms as well as research institutions - in a triple-helix network will have a greater chance of occupying structural holes or encountering novel information. Furthermore, we consider the impact of collaborating with each type of partner - other firms in the supply-chain, competitors, consultancies and research institutions - on firms' level of innovation.

Hypothesis 2b: Firms involved in triple-helix networks with a broad scope will be more innovative than those involved in networks with a more limited scope. 


\section{Geography and the organization of innovation}

A related debate, often neglected in the innovation literature, concerns the geographical scope of networks. Although some arguments advocate that networking can happen 'at national, regional, or increasingly also at international levels' (Etzkowitz and Leydesdorff 2000, p. 118), the majority of the literature has argued for the superiority of local or regional networks. Local and regional networks are perceived as superior because, as much of the knowledge is diffused through face-to-face contact (Gordon and McCann 2000; Porter 1990; Storper and Venables 2004), the effort and costs required to make tacit knowledge circulate over large geographical distances makes triple-helix networking at arm's length much less likely to be effective (Leydesdorff and Fritsch 2006). The conditions under which transactions are best conducted locally include situations of complex information, rapid changes or low volumes (Duranton and Puga 2004; Leamer and Storper 2001), all of which are usually present in new product development processes.

However, others have pointed to the dangers of lock-in and over-embeddedness associated with local interactions with the same partners over an extended period of time (Fitjar and Rodríguez-Pose 2011; Gertler 2003; Moodysson 2008; Uzzi 1996), advocating instead the use of partners outside the comfort zone of local interaction through the development of global pipelines (Bathelt et al. 2004; Morrison et al. 2013). Similarly, from within the triple-helix perspective, Leydesdorff (2012) has argued that triple-helix approaches overcome one of the traditional limitations of regional innovation systems approaches in that they may extend beyond regional (or national) boundaries, making innovation systemic, rather than dependent on a priori defined boundaries. Indeed, in the case of Norway, Strand and Leydesdorff (2013) find that foreign relations are characteristic of the regions with the most efficient triple-helix relations. This is closely related to the industrial composition of these regions with strong petroleum and maritime sectors. Interacting with partners in different geographical contexts increases the chances of occupying structural holes (Burt 1992) and of bridging diverse cognitive frameworks. The need for face-to-face contact can be maintained through temporary proximity (Maskell et al. 2006; Torre 2008) and international business travel (Beaverstock et al. 2009), and knowledge can also be transferred through virtual interaction over the internet, reducing the need for permanent co-location (Bathelt and Turi 2011). On this basis, we present two alternative hypotheses:

Hypothesis 3a: Firms that cooperate with a wide range of regional partners will be more innovative.

Hypothesis 3b: Firms that cooperate with a wide range of international partners will be more innovative.

\section{From knowledge to innovation and commercial success}

As this discussion suggests, the conditions which favour networks - in particular regional ones - and internal organization are similar. In both cases, they involve uncertainty, frequent or repeated interaction, and unique investments of money, time or knowledge. The choice between networks and internal organization under such circumstances is not straightforward. Access to external knowledge indicates an advantage for networks compared to firm organizing. When the ideas are easy to transform and market to your own customers, and knowledge travels easily from its origin to the focal firm, the triple-helix network form may 
be the preferred organizational mode. An interorganizational partnership may also have developed what Kogut and Zander (1992) call 'higher order organizing principles', such as shared goals and cultures, common identities and languages. A long-term partnership may also enable exchange of tacit knowledge, especially if the relations are built on physical, social or cognitive proximity (Boschma 2005). To borrow a concept from evolutionary theory (Burgelman 2002), the variation may be greater in a network than within the boundaries of the focal firm. However, there is more to an innovation process than creativity and ideas.

A successful innovation ends up in a commercial product or service, and the organization of this part of the innovation process is best understood by applying concepts from the contractual approach. In this line of reasoning, the fundamental reason why resources and assets are brought under common ownership in a firm is due to incentive problems that may arise in situations of high asset specificity and a proclivity to opportunism (Williamson 1985). Interconnected or co-specialized resources produce rents that may be appropriated by opportunistic input owners, even in a partnership. Furthermore, when the outcome is uncertain - which is often the case in innovation processes - it may be costly to agree on contracts or negotiate ex post. Uncertainties typically also evolve during the innovation process where some ideas are discarded and novel ones are further explored. In that case, an internal employment contract is more flexible than an incomplete contract between separate firms. Teece (2000) has detailed how considerations of appropriability of rent-yielding knowledge resources influence the way in which innovative activities are organized.

To sum up, there is no straightforward prediction about which type of the three organizations considered will deliver greater innovation and commercial success. Being embedded in triple-helix networks may facilitate the circulation of new ideas, increased variation and may provide complementary assets and knowledge. These complementarities may speed up the innovation process. On the other hand, especially if specific investments are needed to this particular innovation process, contractual issues may evolve. These hard topics may intensify when the outcome of the process is highly uncertain (especially if the upside is potentially huge) and give rise to appropriability issues. In that case, in-house developments are preferred. In this study, we use the share of income that results from innovations (over the last 3 years) as the measure of innovation performance. Highly innovative firms (as measured by a high share) are dependent on income from new products and services. Based on the discussion above, we present two competing hypotheses:

Hypothesis 4a: Firms that develop new innovations within the company will be more innovative than firms that cooperate with other companies or organizations in the development of innovations.

Hypothesis 4b: Firms that cooperate with other companies or organizations in the development of innovations will be more innovative than firms that develop new innovations within the company.

\section{First-mover advantages versus imitation}

A final controversial issue in innovation strategy relates to the degree of novelty (Tidd and Bessant 2009). To capture the degree of novelty, we distinguish between products and services being new to the market and new to the firm. The latter is an imitation or adaptation of something already known, and may, as such, represent an incremental innovation. The literature on firm strategy offers two competing perspectives on this issue. On the one hand, 
imitations and incremental innovations are less imbued with risk and uncertainty than new products and services. The technologies and knowledge are proven, the size of the market is fairly well known, and so are customer tastes and preferences. In a more established market, an accepted market prize is also well documented. Imitators can learn from the mistakes of others and often free ride on the investments of the original innovators. Furthermore, as communication and transportation have advanced, opportunities for imitation have burgeoned. The globalizing economy and technological advances have expanded the ranks of imitators and have made imitation and incremental adaptations more feasible, more cost-effective and much faster (Shenkar 2010).

A competing view is that the introduction of genuinely new products into the market offers first-mover advantages (Lieberman and Montgomery 1988) that allow firms to appropriate an entrepreneurial rent (Schumpeter 1934). Since imitated products and services have already been in the market, there are no first-mover advantages. The entrepreneurial rent has already been appropriated by other firms in the market. According to Lieberman and Montgomery (1988), the first-mover advantages include superior positions in geographical space (prime physical locations), technology space (e.g. patents) or customer perceptual space. New entrants may be able to expand and defend their position by blocking the market with a broader product line. Pioneers may also develop a superior reputation related to their products and services. Furthermore, customers may incur perceived or real switching costs as they accumulate experience with the pioneer's product or service, and network externalities may establish the pioneer's product as a standard in the market (Lieberman and Montgomery 1998). First movers may also gain a head start in developing a set of dynamic capabilities (Teece 2009) that are key to the product or service in question. These capabilities are often referred to as learning or experience curve advantages and are typically more important than patents (Cohen et al. 1997).

Early movers also stand a better chance to dominate the market and earn substantial profits. Such profits fade away, however, as imitators enter the same market. The sustainability of first-mover advantages depends on the initial resources captured by the pioneer and the resources and capabilities subsequently developed, relative to the quality of those held or developed by imitators (Lieberman and Montgomery 1998).

Based on the discussion above, we, once more, present two competing hypotheses:

Hypothesis 5a: Firms that introduce new products into the market will earn a higher share of their income from innovations than firms that introduce products which are similar to existing products.

Hypothesis 5b: Firms that introduce new products which are similar to existing products will earn a higher share of their income from innovations than firms that introduce new products into the market.

\section{Method, variable specifications and descriptive data}

The analysis is based on data from a survey of 1,604 firms located in Norway's five largest city regions: Oslo, Bergen, Stavanger, Trondheim and Kristiansand. It may be argued that Norway represents a well-suited case to study the issues raised in this paper, including the impact of triple helix. Generally, universities are publicly owned, and government has taken substantial ownership of firms in important sectors (banking, energy, telecom, etc). The survey was conducted in 2010 through telephone interviews with the CEO of each 
firm. As the vast majority of firms are small- or medium-sized, we expect the top manager of the firm to be most informed of the innovations in their companies. The median size is 27 employees, and three out of four firms in the sample have 60 employees or less. Firms were drawn randomly from the Norwegian Register of Business Enterprise, where all firms are required by law to register. Survey respondents were sampled among all firms with more than ten employees located in municipalities in which $10 \%$ or more of the population commuted into the core urban municipality(ies) of the city region in 2009 (Leknes 2010). We imposed a quota of 400 firms for each of the three largest city regions, 300 for Trondheim and 100 for Kristiansand. The sampling and interviews were conducted by Synovate (now Ipsos), a professional market research firm. A total of 5,887 firms were approached, with a response rate of $27.2 \%$.

\section{Dependent variable}

In order to obtain data on the relationship between organization mode and innovation performance, we first asked all firms whether they had introduced any goods or services into the market during the past 3 years that were new to the company or significantly improved compared to their existing products. Of the 1,604 firms included in the survey, 857 firms, or $53.4 \%$, answered affirmatively and were classified as innovative firms. These firms were subsequently asked to estimate which percentage share of their income derives from products that were developed within the last 3 years (Innoshare). We elicited 763 responses to this question. The average share of income from new products and services was 24.4, with a standard deviation of 24.9. Figure 1 shows the distribution of the share of income deriving from new products and services across all 763 firms. Because the distribution on the variable is skewed, which could cause problems of heteroscedasticity and non-linearity, we apply a log transformation when fitting the ordinary least squares (OLS) regression model. This is done by adding 1 to the value of Innoshare (in order to avoid taking the log of 0) and then calculating the natural logarithm. The logged variable has mean 2.74, median 2.77 and skewness -0.49 .

\section{Independent variables}

The analysis includes three vectors of independent variables. First, Innomode is a categorical variable measuring how firms organized the innovation processes that resulted in the introduction of new products. Managers of innovative firms were asked if their new products were developed mainly by their own company (Internal mode), mainly by other companies or organizations (External mode) or whether, in a triple-helix way, they cooperated with other companies or organizations in developing them (Cooperation mode). External mode is treated as the baseline, with dummy variables for Internal and Cooperation modes included in the regression model. In total, $47.3 \%$ of firms mainly used the Internal mode, 36.5\% the Cooperation mode, and $14.8 \%$ the External mode, while $1.4 \%$ did not know and were excluded from further analysis.

Second, New-to-market is a dichotomous variable measuring whether the new product or service was new to the market or only new to the firm. Managers were asked whether any of their new products were new to the market or whether they were only new to their company and very similar to a product that already existed in the market. In total, $57.2 \%$ answered that the product innovations were new to the market. Again, 


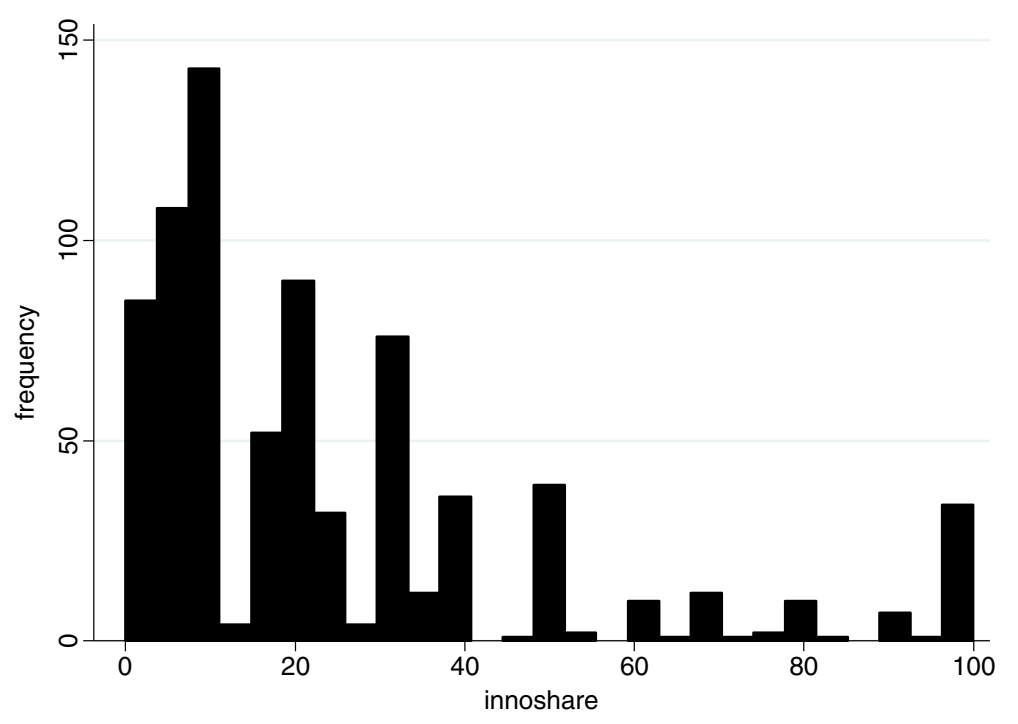

Figure 1 Frequency distribution of Innoshare.

we include a dummy variable for New-to-market innovations against a baseline of newto-firm innovations.

Third, Partners is a vector of three indices measuring the innovative firm's established partnerships with other companies and organizations. As argued above, it is not only the number of partners that may be important. The crucial point may be the number of different partners (Osborn and Hagedoorn 1997). Following our definition of networks, the greater the number of bilateral partnerships, the larger the scope of the network. If these partnerships link firms to socioeconomic agents which are different in the nature (such as research centres, universities and government offices or agencies), the network becomes a triple-helix network. This argument is picked up in our analysis by counting the number of partnerships involving different partner types. Managers were therefore asked whether their firm had cooperated with any of seven different types of partners (other companies within the conglomerate, suppliers, customers, competitors, consultancies, universities and research institutes) in the last 3 years. We expect that the relationship is rather long-lasting and purposely established to gain access to complementary assets. Note that in our conceptualization, networks emerge from firms establishing collaborations with types of partners of a different nature. Therefore, if a firm only establishes partnerships within the supply chain, that would be considered as outsourcing in the market within our framework. If, by contrast, partnerships go beyond the supply chain and involve competitors, consultancies and/or research institutions and this is repeated by multiple agents, a network emerges. We assume that a large number of different types of partners represent evidence of a firm's embeddedness in triple-helix-type networks. For each type of partner, managers were also asked whether the partner(s) were located within their own region, elsewhere in the country and/or abroad. Based on their responses to these questions, we created three indices measuring the firm's network within the region (Regional partners), nationally outside of the region (National partners) and abroad (International partners). Each index is simply a count of the number of different types of partners used at each geographical scale. The average innovative firm used $2.36( \pm 0.12)$ types of regional 
partners, $1.59( \pm 0.11)$ types of national partners, and $1.23( \pm 0.10)$ types of international partners.

In order to assess further the role of networks, we also run a separate analysis in which we measure the impact of collaborating with different types of partners, by respecifying Partners according to the type of partner(s) with whom firms collaborate, rather than the geographical location of these partners. We examine four different basic types of partners, each coded as dummy variables, which take the value 1 if the firm has collaborated with any of its suppliers and/or customers (Supply-chain partners), its competitors (Competitor partners), with consultancy firms (Consultancy partners) or with universities and/or research institutes (RED partners).

\section{Controls}

The analysis controls for a set of factors that could be expected to affect both firms' share of income from new products and services and their values on the independent variables. First, Company size is measured as the natural logarithm of the number of employees in the company. Larger firms are usually older and more established and could be expected to procure comparatively more of their income from existing products. They also have a higher capacity for internal development of innovations and possibly for networking with partners. The average innovative firm in the survey has $80( \pm 14)$ employees, while the median is 27 employees. Seventy-five percent of firms have 60 employees or less. Second, Foreign ownership is measured as the proportion of shares held by nonNorwegian owners. Foreign-owned firms could be expected to have a larger international network and to introduce products and services developed by sister or mother companies elsewhere. In total, $79.6 \%$ of the innovative firms are completely Norwegian owned, while $15.3 \%$ are completely owned by foreigners. The remaining $5.1 \%$ are partly owned by foreigners (50\% or less in $3.7 \%$ of cases). Third, Industry will affect the pace of innovation and therefore the proportion of income emanating from new products. There are also different traditions and cultures for networking and cooperation, and for secrecy about new product development, across industries. We include dummy variables for nine different industries based on the firm's official listing in the Norwegian Register of Business Enterprise by NACE codes. The categories used were mining and quarrying (1.6\% of innovative firms); manufacturing (22.2\%); construction (8.5\%); electricity, gas and water supplies (0.5\%); wholesale and retail trade (19.6\%); food and accommodation services (6.7\%); transportation, storage, information and communication (7.4\%); financial and insurance activities (3.6\%); and other services (29.9\%). We included dummy variables for each category, with Other services as the baseline.

\section{Results and Discussion}

Including the variables described above in the model, we fit the following regression models to the data:

$$
\begin{aligned}
\log _{\mathrm{e}}\left(\text { innoshare }_{i}+1\right)=\alpha & +\beta_{1} \text { Innomode }_{i}+\beta_{2} \text { New-to-market }_{i} \\
& +\beta_{3} \text { Controls }_{i}+\varepsilon_{\mathrm{i}} \\
\log _{\mathrm{e}}\left(\text { innoshare }_{i}+1\right)=\alpha & +\beta_{1} \text { Innomode }_{i}+\beta_{2} \text { New-to-market }_{i} \\
& +\beta_{3} \text { Partners }_{i}+\beta_{4} \text { Controls }_{i}+\varepsilon_{i},
\end{aligned}
$$

where $\alpha$ is a constant, and $\varepsilon$ is an idiosyncratic error with random normal distribution. 
Table 1 shows the results of the analysis for model 1 and model 2. A full set of diagnostic tests have been performed on the analyses, including for non-linearity, multicollinearity, heteroscedasticity and significant outliers. As the latter test revealed some significant outliers, the models were also analysed using a robust regression model. The results from this analysis are shown in the last two columns of Table 1 and produce broadly the same findings as in the OLS model. The Breusch-Pagan test also showed significant heteroscedasticity ( $P=0.04$ for both models). The model is therefore fitted with robust standard errors.

In line with hypothesis 1 and hypothesis 4a, firms that develop new products and services internally earn a significantly higher share of their income from innovations than do firms that procure new product development in the market or in cooperation with other companies or organizations. Firms that are active in networks are also significantly more innovative than those that procure innovation by simple bilateral, commercial interaction in the market, supporting hypothesis 2 . The log share of income from innovation in the group developing new products internally is 0.59 higher than among firms who hire external companies or organizations to develop new products for them (market mode), and 0.36 higher than among firms who cooperate with others (triplehelix network mode). Furthermore, the log share of income among firms using the network mode is 0.23 higher than among firms using the market mode. This difference is significant at the $90 \%$ level. However, when we control for Partners, the difference between the latter two groups falls to 0.20 and is no longer statistically significant, suggesting that the impact of collaborating with partners depends crucially on how many types of partners the firm collaborates with, as well as where these are located. The

Table 1 OLS and robust regression estimations of the empirical models

\begin{tabular}{lllll}
\hline Outcome: log(Innoshare + 1) & Model 1 & Model 2 & Model 1 robust & Model 2 robust \\
\hline Internal & $0.59^{* * *}(0.12)$ & $0.55^{* * *}(0.12)$ & $0.59^{* * *}(0.12)$ & $0.54^{* * *}(0.12)$ \\
Cooperation & $0.23^{*}(0.12)$ & $0.20(0.12)$ & $0.22^{*}(0.12)$ & $0.19(0.12)$ \\
New-to-market & $0.24^{* * *}(0.08)$ & $0.19^{* *}(0.08)$ & $0.19^{* *}(0.08)$ & $0.15^{*}(0.08)$ \\
Regional partners & & $-0.00(0.02)$ & & $-0.01(0.02)$ \\
National partners & & $0.03(0.03)$ & & $0.02(0.03)$ \\
International partners & & $0.10^{* * *}(0.03)$ & & $0.10^{* * *}(0.03)$ \\
Company size & $-0.18^{* * *}(0.04)$ & $-0.21^{* * *}(0.04)$ & $-0.18^{* * *}(0.04)$ & $-0.20^{* * *}(0.04)$ \\
Foreign ownership & $0.05(0.10)$ & $-0.07(0.11)$ & $-0.01(0.11)$ & $-0.14(0.11)$ \\
Mining & $0.42(0.31)$ & $0.38(0.31)$ & $0.40(0.32)$ & $0.30(0.31)$ \\
Manufacturing & $-0.29^{* * *}(0.10)$ & $-0.27^{* * *}(0.10)$ & $-0.30^{* * *}(0.10)$ & $-0.30^{* * *}(0.10)$ \\
Electricity, gas and water supplies & $-0.15(0.21)$ & $-0.16(0.29)$ & $-0.23(0.74)$ & $-0.24(0.73)$ \\
Construction & $-0.15(0.16)$ & $-0.08(0.16)$ & $-0.25(0.15)$ & $-0.18(0.15)$ \\
Wholesale and retail trade & $-0.27^{* *}(0.11)$ & $-0.25^{* *}(0.11)$ & $-0.29^{* *}(0.11)$ & $-0.28^{* *}(0.12)$ \\
Hotels and restaurants & $-0.39^{* *}(0.16)$ & $-0.31^{*}(0.17)$ & $-0.44^{* *}(0.18)$ & $-0.36^{* *}(0.17)$ \\
Transport and communications & $-0.13(0.17)$ & $-0.10(0.16)$ & $-0.09(0.16)$ & $-0.07(0.16)$ \\
Financial services & $-0.76^{* * *}(0.24)$ & $-0.77^{* * *}(0.24)$ & $-0.69^{* * *}(0.21)$ & $-0.70^{* * *}(0.21)$ \\
Constant & $3.06^{* * *}(0.18)$ & $3.03^{* * *}(0.20)$ & $3.15^{* * *}(0.18)$ & $3.15^{* * *}(0.18)$ \\
Number & 752 & 752 & 752 & 752 \\
$R^{2}$ & 0.12 & 0.14 & & \\
\hline Table shows regression coefficients, with robust standard errors enclosed in parentheses. ${ }^{*}=\mathrm{P}<0.10, * *=P<0.05, * * * P<0.01$.
\end{tabular}


difference between internal organization and the two other modes also falls slightly - to 0.55 and 0.35 compared to market organization and networks, respectively, - but remains significant. Figure 2 shows the expected values of $\log ($ Innoshare +1$)$ for firms in the three groups, controlling all other variables at their means. The dotted lines represent 95\% confidence intervals of the estimates. The expected share of income for new products or services for an average firm that develops innovations internally is $e^{2.95}-1=18.2 \%$. For a firm that uses a network mode, it is $e^{2.60}-1=12.4 \%$, and for a firm that hires other companies or organizations to develop its innovation, the predicted share is $e^{2.37}-1=9.7 \%$.

Firms that develop products which are new to the market also earn a significantly higher share of their income from new products than firms who are early adopters and introduce products which are only new to the firm, supporting hypothesis $5 \mathrm{a}$, rather than $5 \mathrm{~b}$. The log share of income from new products is 0.24 higher for firms that introduce products that are new to the market. For an average firm with an early adoption strategy, the fitted value of Innoshare is $e^{2.60}-1=12.4 \%$, whereas it is $e^{2.83}-1=16.0 \%$ for a first mover. The effect of introducing original products is somewhat weaker when some influential outliers are weighted down in the robust regression analysis, but it is still positive and significant.

Model 2 introduces a third independent variable, Partners. This reduces the effect of each of the other independent variables and makes the difference between the network mode and the market mode no longer statistically significant. As for the effect of

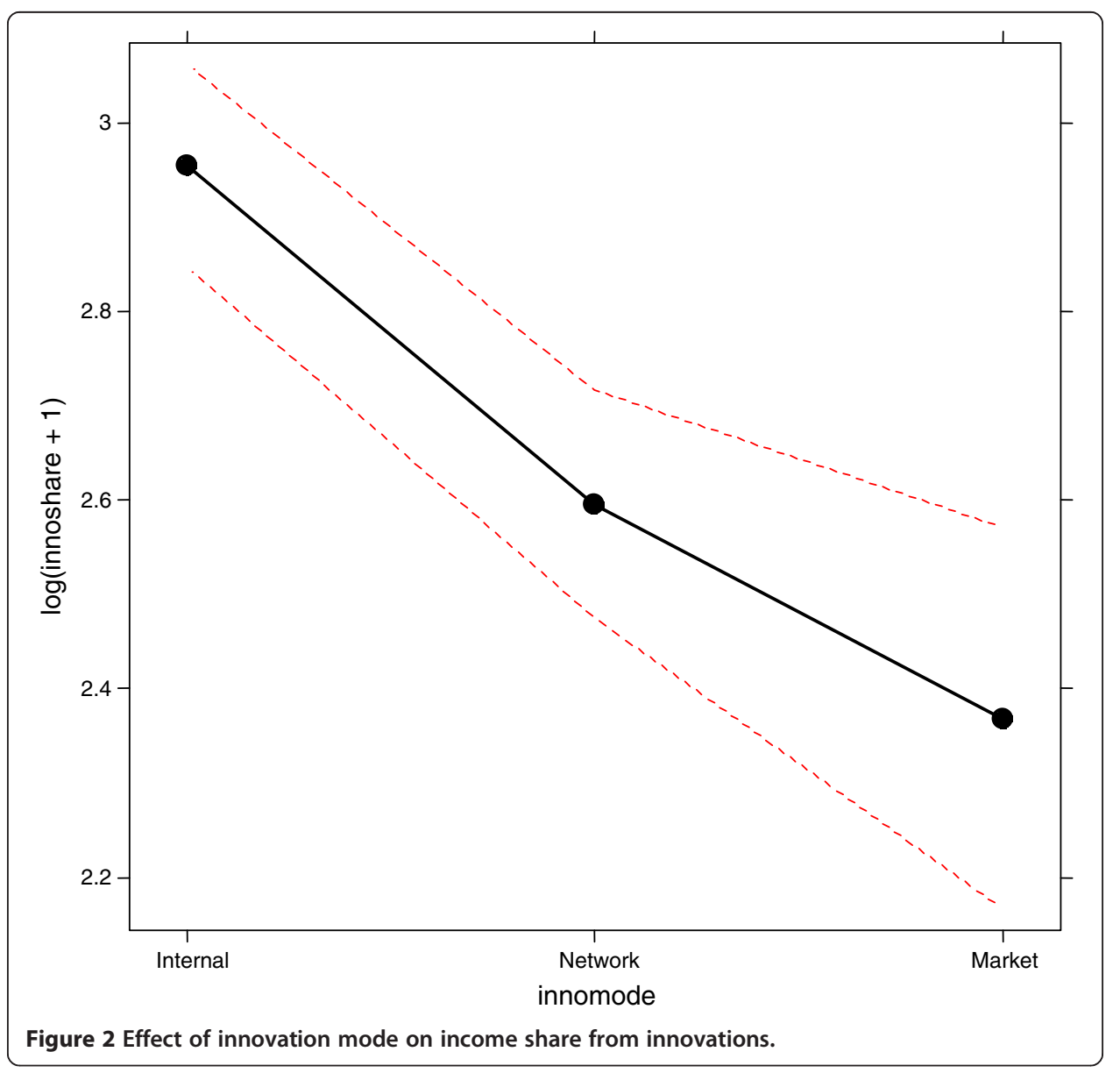


partnerships, neither regional nor national partners make a difference for the firms' share of innovation income. Hypothesis 3a is therefore not supported. However, collaborating with a wide range of international partners has a strong and significant positive effect on innovation income, supporting hypothesis $3 \mathrm{~b}$. For each additional type of international partner with which the firm collaborates, its log share of income from new products increases by 0.10 . Contrary to expectations in much of the literature, the development of local triple-helix networks yields much lower returns than engaging in wider geographical networks, at least in the case of Norway. International network development delivers greater innovation and firm-level income and profits than networking at close quarters in what are relatively small local and national markets. As Leydesdorff (2012) suggests, the sources of innovation at firm level in Norway may have become systemic rather than constrained by local or national boundaries.

Figure 3 plots the fitted values of $\log ($ Innoshare +1$)$ at different levels of International partners, controlling all other variables at their means. The dotted lines represent $95 \%$ confidence intervals of the estimates. The expected share of income from innovation increases from $e^{2.61}-1=12.6 \%$ for a firm that does not cooperate with any foreign partners to $e^{3.30}-1=26.1 \%$ for the rare case of a firm which is completely embedded in international triple-helix-type networks and cooperates with all seven types of foreign partners. Introducing this additional variable into the model also increases the explained variance from 0.12 to 0.14 .

Among the control variables, company size has a significant negative effect on innovation income. As expected, larger firms earn more of their income from established products. Unlike foreign partnerships, foreign ownership does not affect the share of income from new products. Controlling for the other variables in the model, Norwegian and foreign-owned firms earn a similar proportion of their income from new products. In terms of industry, firms in 'other services' (these are mostly knowledge-intensive services, e.g. real estate, legal services, accountancy, consultancy and marketing) tend to earn a comparatively higher share of their income from new products and services. Only mining has a - non-significant - positive coefficient compared to the baseline, whereas four industries have significantly less income from innovation than 'other services': wholesale and retail trade, manufacturing, hotels and restaurants, and financial services. The share of income from new products is by far the lowest in the latter group, with a log share that is 0.77 lower than among firms in 'other services'.

In Table 2, we specify two new models that represent different specifications of the regression equations presented in model 2. Model 3 is identical to model 2 with the exception that the vector Partners is now a measure of the types of partners, rather than their geographical location, as detailed in the section on independent variables. For the variables Innomode and New-to-market, as well as for the controls, the results are consistent with model 2, with only minor changes in the coefficients. The coefficients of interest in this case are those associated with the dummy variables for different types of partners. In model 3, we simply include the four different indicators and examine if interaction with any of the four types of partners has an impact on the innovation levels of the firm. The analysis shows that two of the four variables (Supply-chain partners and RED partners) have a positive and significant effect on Innoshare. The average firm that does not collaborate with supply-chain partners has a predicted value of 


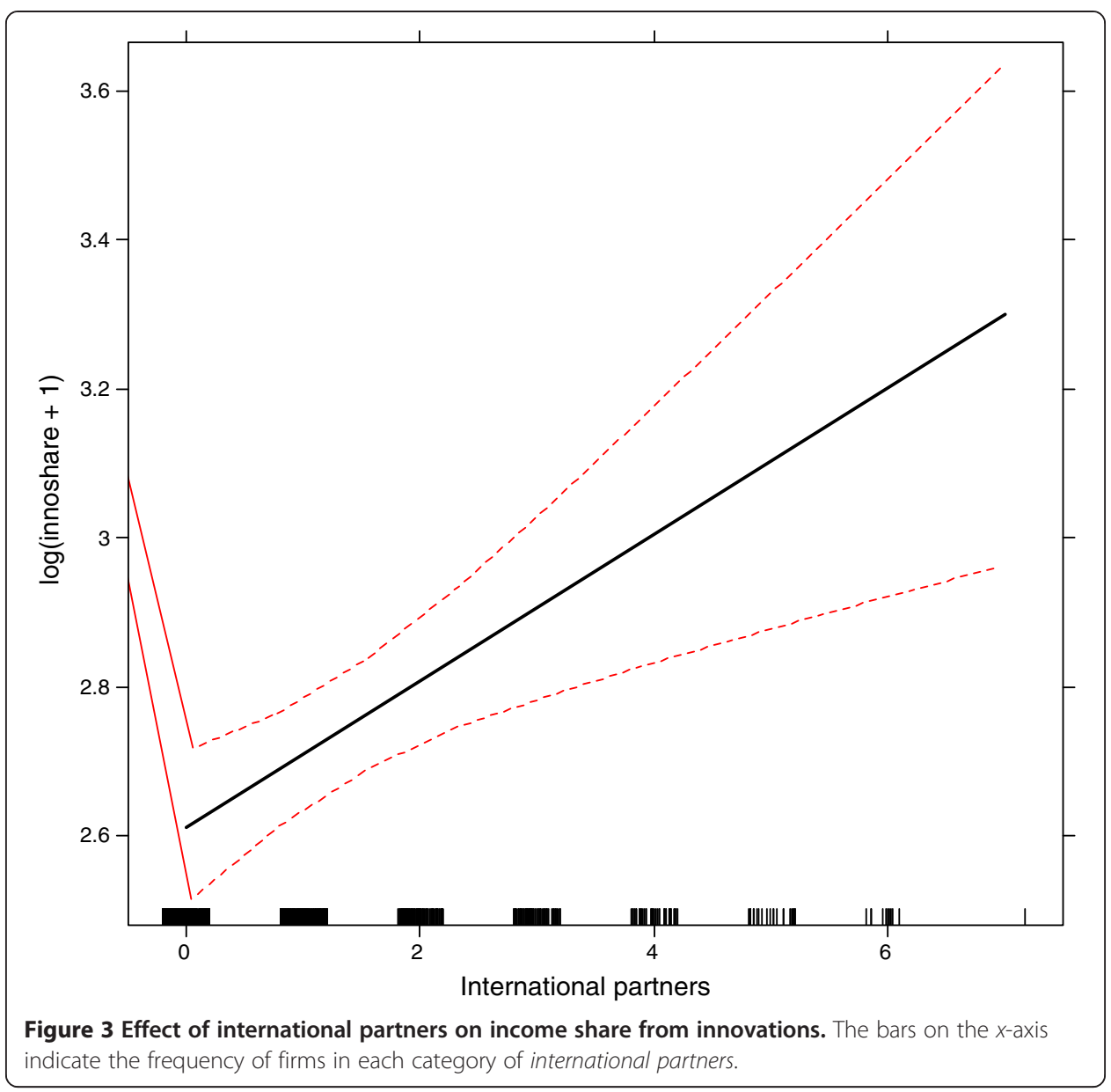

Innoshare of $e^{2.44}-1=10.5 \%$, compared to $e^{2.76}-1=14.8 \%$ for firms that do. Firms that do not collaborate with R\&D partners have a predicted value of $e^{2.67}-1=13.4 \%$, while the predicted value for those that do is $e^{2.84}-1=16.1 \%$. For the other two types of partners (competitors and consultancies), the effect is negative, but not significant.

In model 4, we further include an interaction between the two key types of triplehelix partners that were found to have a significant impact on Innoshare in model 3. This analysis examines the interaction between collaboration within the supply chain and with research institutions by specifying three dummy variables: one for firms that collaborate with supply-chain partners only, one for firms that collaborate with R\&D partners only, and one for firms that collaborate with both supply-chain and R\&D partners. These three variables are compared against a baseline of firms that collaborate with neither supply chain nor R\&D partners. The results show that collaborating with both supply chain and $R \& D$ partners is associated with the highest share of income from new products, $e^{2.85}-1=16.3 \%$. Interaction with supply-chain partners only also has a significant positive effect, while the effect of interaction with R\&D partners is positive, but not statistically significant. The predicted value of Innoshare is $e^{2.69}-1=$ $14.7 \%$ for firms that collaborate with supply-chain partners only, and $e^{2.82}-1=15.8 \%$ for firms that collaborate with R\&D partners only. The lowest levels of innovation are found among firms that collaborate with neither supply-chain nor R\&D partners, where the expected value is $e^{2.32}-1=9.2 \%$. While the analysis show that the most innovative 
Table 2 OLS regression estimations: testing for type of partner

\begin{tabular}{lll}
\hline Outcome: log(Innoshare + 1) & Model 3 & Model 4 \\
\hline Internal & $0.56^{* * *}(0.13)$ & $0.57^{* * *}(0.13)$ \\
Cooperation & $0.20(0.13)$ & $0.21(0.13)$ \\
New-to-market & $0.21^{* * *}(0.08)$ & $0.21^{* *}(0.08)$ \\
Supply-chain partners (only) & $0.31^{*}(0.17)$ & $0.37^{*}(0.19)$ \\
Competitor partners & $-0.06(0.08)$ & $-0.06(0.08)$ \\
Consultancy partners & $-0.03(0.08)$ & $-0.03(0.08)$ \\
R\&D partners (only) & $0.17^{* *}(0.08)$ & $0.49(0.43)$ \\
Supply-chain and R\&D partners & & $0.53^{* * *}(0.19)$ \\
Company size & $-0.20^{* * *}(0.04)$ & $-0.20^{* * *}(0.04)$ \\
Foreign ownership & $0.04(0.10)$ & $0.04(0.10)$ \\
Industry fixed effects & Yes & Yes \\
Constant & $2.82^{* * *}(0.25)$ & $2.77^{* * *}(0.27)$ \\
Number & 752 & 752 \\
$R^{2}$ & 0.13 & 0.13 \\
\hline Table shows regression coefficients, with robust standard errors enclosed in parentheses* ${ }^{*}=\mathrm{P}<0.10^{* *}=\mathrm{P}<0.05 * 5^{* * *}=\mathrm{P}<0.01$
\end{tabular}

Table shows regression coefficients, with robust standard errors enclosed in parentheses. ${ }^{*}=P<0.10,{ }^{* *}=P<0.05,{ }^{* * *}=P<0.01$.

firms collaborate with both supply-chain and R\&D partners, they do not show a positive interaction between the two types of collaboration, as the sum of the coefficients for supply-chain partners only and R\&D partners only is larger than the coefficient for collaborating with both $(0.37+0.49>0.53)$. However, this difference is not statistically significant. The other coefficients in the model change very little from model 3.

Table 3 shows an analysis of the interaction between the mode of innovation - hierarchy, triple-helix network or market - and whether or not firms have established partnerships with any of the critical innovation partners - other firms in the supply-chain and/or R\&D institutions. The analysis shows that there is very little difference between the three modes of innovation when the firm does not cooperate with other firms in its supply-chain or with R\&D institutions. However, when such partners are present, the hierarchy and network modes become much more efficient than the market mode. In particular, three constellations stand out as being associated with significantly higher shares of income from new products compared to the baseline. The highest level of innovation can be found among firms in the network mode that cooperate with R\&D institutions. Firms that organize their innovation processes internally, but also have strong links within the supply-chain, are also significantly more innovative, in particular if they also collaborate with R\&D institutions.

\section{Conclusion}

Our analysis has highlighted that the organization of the innovation effort in firms, as well as its geographical dimension, makes a difference to the product innovation performance of firms. If innovation processes are organized in contrasting ways, the returns to product innovation may be significantly greater. On the one hand, companies that develop product and service innovations based on internal hierarchy seem to derive a significantly higher share of their income from innovation, compared to those relying on simple dyadic partnerships for sourcing innovation from the market. However, the apparent superiority of internal hierarchy for product innovation is challenged 
Table 3 OLS regression estimations: interacting Innomode with type of partner

\begin{tabular}{|c|c|}
\hline Outcome: log(Innoshare + 1) & Model 5 \\
\hline Internal with no supply-chain or R\&D partners & Baseline \\
\hline Internal + R\&D partners & $0.50(0.77)$ \\
\hline Internal + supply-chain partners & $0.54^{* *}(0.25)$ \\
\hline Internal + supply-chain + R\&D partners & $0.75^{* * *}(0.25)$ \\
\hline Cooperation with no supply-chain or R\&D partners & $-0.04(0.40)$ \\
\hline Cooperation $+R \& D$ partners & $0.85^{* * *}(0.25)$ \\
\hline Cooperation + supply-chain partners & $0.21(0.25)$ \\
\hline Cooperation + supply-chain + R\&D partners & $0.28(0.26)$ \\
\hline External with no supply-chain or R\&D partners & $-0.01(0.56)$ \\
\hline External + R\&D partners & $0.18(0.39)$ \\
\hline External + supply-chain partners & $-0.03(0.28)$ \\
\hline External + supply-chain + R\&D partners & $0.05(0.31)$ \\
\hline New-to-market & $0.21^{* * *}(0.08)$ \\
\hline Company size & $-0.20^{* * *}(0.04)$ \\
\hline Foreign ownership & $0.04(0.10)$ \\
\hline Industry fixed effects & Yes \\
\hline Constant & $3.11^{* * *}(0.29)$ \\
\hline Number & 752 \\
\hline$R^{2}$ & 0.14 \\
\hline
\end{tabular}

when more complex external networks are considered. The participation in broadbased networks, involving different types of socioeconomic agents - as advocated in the triple-helix approach - in the development of new products and services is also associated with earning a higher share of income from innovation compared to conducting product development through market mechanisms. In the latter case, a crucial point is that the network needs to be sufficiently wide to avoid lock-in and overembeddedness. If networks include a broad scope of different partners, both in terms of their geography and the type of partner, their impact on innovation may be very large indeed. If the network is too narrow and constrained, it might have no impact at all.

Our analysis highlights that innovation and the rewards from innovation can be achieved by different forms of organization within the firm, ranging from pure internal sourcing to multiple cooperations with partners of diverse origin. These findings have implications for firms deciding how to organize their product innovation processes. In light of the increasing tendency for firms to split up their value chains and outsource parts of the production and innovation process to external actors, it is noteworthy that those firms which organize the development of new products internally tend to reap greater returns. This might prompt some firms to reconsider how they organize new product development. However, the findings also suggest a different route that may provide even greater rewards: Developing new products together with external partners that are sufficiently diverse - in terms of geographical location and function, including partners from the supply-chain and from R\&D communities - can produce significant returns. Hence, if firms choose to outsource parts of the innovation process, the 
greatest returns may stem from working in close cooperation with their partners rather than at arm's-length and from involving a sufficiently wide network of partners in the way proposed by the triple-helix approach.

Having said that, it has to be borne in mind that the study has several shortcomings. First, we have only differentiated between truly novel and imitated innovations. A finer distinction between innovations, for instance the degree of tacit knowledge and other knowledge modes, the scope of uncertainties and the longevity of the partnerships could facilitate more precise predictions. Furthermore, by linking the different strands of theory to evolutionary perspectives on innovation processes, we could have detailed the innovation process and discussed where in that process the different organization modes may be more efficient. For instance, as documented above, the number of different international partners facilitates more product and service innovation than fewer and more local partners. Is that effect primarily linked to the early phases of the process by offering more ideas, or does it also include the appropriation phase? Finally, the study is limited to firms in Norway, which is a high-trust society where network organization may be more effective, and which therefore has a long tradition of inter-firm cooperation in innovation processes. It is also a small country with a relatively limited market in many areas, reducing the potential for outsourcing parts of the innovation process. While all of these questions merit further research, the study has shown that involvement in purpose-built triple-helix-type international networks is more important for Norwegian firms than local interaction for the generation of innovation and economic dynamism. This contributes to the triple-helix approach in underlining that triple-helix networks must be of sufficient scope - in terms of geography as well as type of partner - in order to deliver the expected benefits.

\section{Additional file}

Additional file 1: Multilingual abstracts in the five official working languages of the United Nations and Portuguese.

\section{Competing interests}

The authors declare that they have no competing interests.

Authors' contributions

All authors contributed equally to this research. They all read and approved the final manuscript.

\section{Acknowledgement}

The final draft of the article has benefitted from the comments of the anonymous referees. The authors would also like to acknowledge the generous financial support of the Stavanger Centre for Innovation Research, the Regional Research Council for Western Norway, and the European Research Council under the European Union's Seventh Framework Programme (FP7/2007-2013)/ERC grant agreement nº 269868.

\section{Author details}

${ }^{1}$ UiS Business School, University of Stavanger, Stavanger 4036, Norway. ${ }^{2}$ Stavanger Centre for Innovation Research, International Research Institute of Stavanger, PO Box 8046, N-4068 Stavanger, Norway. ${ }^{3}$ London School of Economics and Political Science, Houghton Street, London WC2A 2AE, United Kingdom.

Received: 31 January 2014 Accepted: 18 June 2014

Published online: 16 October 2014

References

Argyres N (1996) Evidence on the role of firm capabilities in vertical integration decisions. Strateg Manag J 17(2):129-150

Audretsch DB, Keilbach M (2007) The theory of knowledge spillover entrepreneurship. J Manag Stud 44:1242-1254

Barney J (1991) Firm resources and sustained competitive advantage. J Manag 17(1):99-120

Barney JB, Ouchi WG (1986) Organizational Economics. Jossey-Bass, San Francisco

Barzel Y (1981) Competitive tying arrangements: the case of medical insurance. Econ Inq 19(4):598-613 
Bathelt H, Turi P (2011) Local, global and virtual buzz: the importance of face-to-face contact in economic interaction and possibilities to go beyond. Geoforum 42(5):520-529

Bathelt H, Malmberg A, Maskell P (2004) Clusters and knowledge: local buzz, global pipelines and the process of knowledge creation. Prog Hum Geogr 28(1):31-56

Baum JAC, Oliver C (1991) Institutional linkages and organizational mortality. Adm Sci Q 36:187-218

Beaverstock JV, Derudder B, Faulconbridge JR, Witlox F (2009) International business travel: some explorations. Geografiska Annaler: Series B, Human Geography 91(3):193-202

Boschma RA (2005) Proximity and innovation: a critical assessment. Reg Stud 39(1):61-74

Burgelman RA (2002) Strategy is destiny. The Free Press, New York

Burt RS (1992) Structural holes. Harvard University Press, Cambridge

Burt RS (2004) Structural holes and good ideas. Am J Sociol 110:349-349

Chesbrough H (2003) Open innovation: the new imperative for creating and profiting from technology. Harvard Business School Press, Boston

Coase $R$ (1937) The nature of the firm. Economica 4:386-405

Cohen W, Nelson RR, Walsh J (1997) Appropriability conditions and why firms patent and why they do not in the American manufacturing sector. Carnegie-Mellon University, Pittsburgh

Conner KR (1991) A historical comparison of resource-based theory and five schools of thought within industrial organization economics: do we have a new theory of the firm? J Manag 17:121-154

Conner KR, Prahalad CK (1996) A resource-based theory of the firm: knowledge versus opportunism. Organ Sci 7 (5):477-501

Dodgson M (2014) Collaboration and innovation management. In: Dodgson M, Gann DM, Phillips N (eds) The Oxford Handbook of Innovation Management. Oxford University Press, Oxford

Dosi G, Kogut B (1992) National specificities and the context of change: the coevolution of organization and technology. In: Kogut B (ed) Country competitiveness: technology and the organization of work. Oxford University Press, New York

Duranton G, Puga D (2004) Micro-foundations of urban agglomeration economies. In: Henderson JV, Thisse JF (eds) Handbook of regional and urban economics, vol 4, Vol. Elsevier, Amsterdam, pp 2063-2117

Etzkowitz H (2003) Innovation in innovation: the Triple Helix of university-industry-government relations. Soc Sci Inf 42:293-337

Etzkowitz H (2008) The triple helix: university-industry-government innovation in action. Routledge, New York

Etzkowitz H, Leydesdorff L (2000) The dynamics of innovation: from National Systems and "Mode 2" to a Triple Helix of university-industry-government relations. Res Policy 29:109-123

Fitjar RD, Rodríguez-Pose A (2011) When local interaction does not suffice: sources of firm innovation in urban Norway. Environ Planning A 43:1248-1267

Fitjar RD, Rodríguez-Pose A (2013) Firm collaboration and modes of innovation in Norway. Res Policy 42(1):128-138

Foss NJ (1996) Knowledge-based approaches to the theory of the firm: some critical comments. Organ Sci 7(5):470-476

Foss NJ, Laursen K, Pedersen T (2011) Linking customer interaction and innovation: the mediating role of new organizational practices. Organ Sci 22:980-999

Gertler MS (2003) Tacit knowledge and the economic geography of context, or, the undefinable tacitness of being (there). J Econ Geogr 3:75-99

Glaeser E (2011) Triumph of the city: how our greatest invention makes us richer, smarter, greener, healthier and happier. Macmillan, New York

Gordon IR, McCann P (2000) Industrial clusters: complexes, agglomeration and/or social networks? Urban Stud 37:513-532

Granovetter M (1985) Economic action and social structure: the problem of embeddedness. Am J Sociol 91(3):481-510

Granovetter M (1992) Economic institutions as social constructions: a framework for analysis. Acta Sociologica 35(1):3-11

Grossman SJ, Hart OD (1986) The costs and benefits of ownership: a theory of vertical and lateral integration. J Polit Econ 94(4):691-719

Gulati R, Lawrence PR, Puranam P (2005) Adaptation in vertical relationships: beyond incentive conflict. Strateg Manag J 26(5):415-441

Kakabadse N, Kakabadse A (2000) Critical review-outsourcing: a paradigm shift. J Manage Dev 19(8):670-728

Kogut B, Zander UB (1992) Knowledge of the firm, combinative capabilities, and the replication of technology. Organ Sci 3:383-397

Kogut B, Zander UB (1996) What firms do? Coordination, identity, and learning. Organ Sci 7(5):502-518

Langlois RN (1992) Transaction-cost economics in real time. Ind Corp Chang 1(1):99-127

Laursen K, Salter A (2006) Open for innovation: the role of openness in explaining innovation performance among UK manufacturing firms. Strateg Manag J 27(2):131-150

Leamer EE, Storper M (2001) The economic geography of the internet age. J Int Bus Stud 32(4):641-665

Leknes E (2010) Fremveksten av byregioner i Norge. In: Farsund AA, Leknes E (eds) Norske byregioner: utviklingstrekk og styringsutfordringer. Høyskoleforlaget, Kristiansand, pp 55-93

Leydesdorff L (2000) The Triple Helix: an evolutionary model of innovations. Res Policy 29:243-255

Leydesdorff L (2012) The Triple-Helix, Quadruple Helix, ..., and an N-tuple of Helices: explanatory models for analyzing the knowledge-based economy? J Knowledge Econ 3(1):25-35

Leydesdorff L, Fritsch M (2006) Measuring the knowledge base of regional innovation systems in Germany in terms of a Triple Helix dynamics. Res Policy 35:1538-1553

Leydesdorff L, Mayer M (2006) Triple Helix indicators of knowledge-based innovation systems: introduction to the special issue. Res Policy 35:1441-1449

Leydesdorff L, Dolfsma W, van der Panne G (2006) Measuring the knowledge base of an economy in terms of Triple Helix relations among technology, organization, and territory. Res Policy 35:181-199

Lieberman MB, Montgomery DB (1988) First-mover advantages. Strateg Manag J 9(S1):41-58

Lieberman MB, Montgomery DB (1998) First-mover (dis)advantages: retrospective and link with the resource-based view. Strateg Manag J 19:1111-1125 
Macneil IR (1980) The new social contract: an inquiry into modern contractual relations. Yale University Press, New Haven Maskell P, Bathelt H, Malmberg A (2006) Building global knowledge pipelines: the role of temporary clusters. Eur Plan Stud 14(8):997-1013

Moodysson J (2008) Principles and practices of knowledge creation: on the organization of "buzz" and "pipelines" in life science communities. Econ Geogr 84(4):449-469

Morrison A, Rabellotti R, Zirulia L (2013) When do global pipelines enhance the diffusion of knowledge in clusters? Econ Geogr 89(1):77-96

Nickerson J, Zenger T (2004) A knowledge-based theory of the firm: the problem-solving perspective. Organ Sci 15:617-632

Osborn RN, Hagedoorn J (1997) The institutionalization and evolutionary dynamics of interorganizational alliances and networks. Acad Manag J 40:261-278

Peteraf M, Helfat CE (2003) The dynamic resource-based view: capability lifecycles. Strateg Manag J 24(10):997

Polanyi K (1944) The great transformation. Rinehart, New York

Porter ME (1990) The competitive advantage of nations. The Free Press, New York

Porter ME (1998) Clusters and the new economics of competition. Harv Bus Rev 76(6):77-90

Powell WW (1990) Neither market nor hierarchy: network forms of organization. Res Organ Behav 12:295-336

Quinn JB, Hilmer FG (1994) Strategic outsourcing. Sloan Manage Rev 35(4):43-55

Ranga M, Etzkowitz H (2013) Triple helix systems: an analytical framework for innovation policy and practice in the knowledge society. Ind High Educ 27(4):237-262

Roper S, Du J, Love JH (2008) Modeling the innovation value chain. Res Policy 37:961-977

Schumpeter JA (1934) The theory of economic development. Harvard University Press, Cambridge

Shenkar O (2010) Copycats: how smart companies use imitation to gain a strategic edge. Harvard Business Press, Boston

Stogdill R (1959) Individual behavior and group achievement. Oxford University Press, New York

Storper M, Venables AJ (2004) Buzz: face-to-face contact and the urban economy. J Econ Geogr 4(4):351-370

Strand $\varnothing$, Leydesdorff L (2013) Where is synergy indicated in the Norwegian innovation system? Triple-Helix relations among technology, organization, and geography. Technol Forecast Soc Chang 80(3):471-484

Tapscott D, Williams AD (2006) Wikinomics: how mass collaboration changes everything. Portfolio, New York

Teece DJ (2000) Managing intellectual capital. Oxford University Press, Oxford

Teece DJ (2007) Explicating dynamic capabilities: the nature and microfoundations of (sustainable) enterprise performance. Strateg Manag J 28(13):1319-1350

Teece DJ (2009) Dynamic capabilities and strategic management. Oxford University Press, Oxford

Teece DJ, Pisano G, Shuen A (1997) Dynamic capabilities and strategic management. Strateg Manag J 18(7):509-533

Tidd J, Bessant J (2009) Managing innovation: integrating technological, market and organizational change, 4th edn. Wiley, Chichester

Torre A (2008) On the role played by temporary geographical proximity in knowledge transmission. Reg Stud 42 (6):869-889

Uzzi B (1996) The sources and consequences of embeddedness for the economic performance of organizations: the network effect. Am Sociol Rev 61(4):674-698

Von Hippel E (1988) The sources of innovation. MIT Press, Cambridge

Williamson O (1973) Markets and hierarchies: some elementary considerations. Am Econ Rev 63(2):316-325

Williamson OE (1985) The economic institutions of capitalism: firms, markets, relational contracting. The Free Press, New York

Williamson OE (1991) Comparative economic organization: the analysis of discrete structural alternatives. Adm Sci Q $36: 269-296$

doi:10.1186/s40604-014-0003-0

Cite this article as: Fitjar et al.: Organizing product innovation: hierarchy, market or triple-helix networks? Triple Helix 2014 1:3.

\section{Submit your manuscript to a SpringerOpen ${ }^{\circ}$ journal and benefit from:}

- Convenient online submission

- Rigorous peer review

- Immediate publication on acceptance

- Open access: articles freely available online

- High visibility within the field

- Retaining the copyright to your article

Submit your next manuscript at $\boldsymbol{\Delta}$ springeropen.com 